\title{
Tuberculous Lymphadenitis in Children
}

\section{Çocukluk Çağında Tüberküloz Lenfadenit}

\author{
Sevgi Yaşar Durmuş(iD), Gönül Tanır²(iD), Ayşe Kaman²(iD), Türkan Aydın Teke2(iD), Rumeysa Yalçınkaya²(iD), \\ Fatma Nur Öz²(ID), Ayşe Beştepe Özbek(iD), İsmet Faruk Özgüner(iD), Ayşe Seçil Ekşioğlư (ID) \\ ${ }^{1}$ Clinic of Child Infectious Diseases, Kayseri City Training and Research Hospital, Kayseri, Turkey \\ ${ }^{2}$ Clinic of Child Infectious Diseases, Dr. Sami Ulus Maternity and Child Health and Diseases, Training and Education Hospital, Ankara, Turkey \\ ${ }^{3}$ Division of Pathology, Dr. Sami Ulus Maternity and Child Health and Diseases, Training and Education Hospital, Ankara, Turkey \\ ${ }^{4}$ Clinic of Pediatric Surgery, Dr. Sami Ulus Maternity and Child Health and Diseases, Training and Education Hospital, Ankara, Turkey \\ ${ }^{5}$ Clinic of Pediatric Pathology, Dr. Sami Ulus Maternity and Child Health and Diseases, Training and Education Hospital, Ankara, Turkey
}

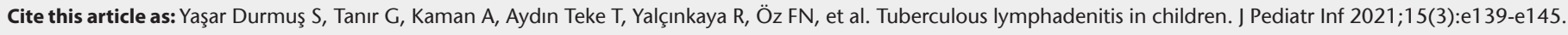

\begin{abstract}
Objective: Tuberculous lymphadenitis is the most common extrapulmonary tuberculosis in childhood. Due to absence of specific tuberculous lymphadenitis symptoms, diagnosis is often delayed. In this study, it was aimed to reveal the diagnostic methods, treatment and follow up results by retrospectively examining the pediatric patients diagnosed with tuberculous lymphadenitis in our hospital.
\end{abstract}

Material and Methods: Demographic, clinical, radiological, microbiological and histopathological features of pediatric patients diagnosed with tuberculous lymphadenitis in Pediatric Infectious Diseases Clinic of our hospital, between 2012-2019, were retrospectively evaluated from medical records.

Results: Of the patients, diagnosed with tuberculous lymphadenitis, 10 (58.8\%) were girl, seven (41.2\%) were boy. Age range was 5-192 months, mean age was $88.7 \pm 63$ months. None of patients had known tuberuculous exposure. The most common complaint was swelling on lymph node region. Median complaint time was 60 days, min: 5- max: 4800 days. The most common enlarged lymph node localization was cervical region. Tuberculin skin test was positive in $15(88.2 \%)$ patients, interferon gamma releasing assay was performed in 13 patients and was positive in 12 (92.3\%). Chest X-Ray was normal in $12(70.2 \%)$ patients. Computered thorax tomography was performed for five (29.4\%) of remaining patients and one patient was diagnosed with pulmonary tuberculosis. Lymph node biopsy was performed in 14 patients. By histopathological and microbiological evaluation of tissue samples; bacille was seen in two patients (14\%) via Ehrlich-Zhiel-Neelsen staining, Mycobacterium tuberculosis polimerase chain reaction positivity in five (83\%) patients and $M$. tuberculosis culture
Öz

Giriş: Tüberküloz lenfadenit çocukluk çağında en sık görülen ekstrapulmoner tüberkülozdur. Tüberküloz lenfadenite özgün bulgular olmaması nedeniyle tanısı sıklıkla gecikir. Bu çalışmada, hastanemizde tüberküloz lenfadenit tanısı alan çocuk hastaların geriye dönük olarak incelenerek tanısal yolların, tedavi ve izlem sonuçlarının ortaya konulması amaçlanmıştır.

Gereç ve Yöntemler: Hastanemiz Çocuk Enfeksiyon Hastalıkları Kliniği'nde 2012-2019 yılları arasında tüberküloz lenfadenit tanısı alan çocuk hastaların demografik, klinik, radyolojik, mikrobiyolojik ve histopatolojik özellikleri tıbbi kayıtlardan geriye dönük olarak incelendi.

Bulgular: Tüberküloz lenfadenit tanılı hastaların 10'u (\%58.8) kız, yedisi (\%41.2) erkekti. Yaş aralığı 5-192 ay, ortalama yaş $88.7 \pm 63$ aydı. Hiçbir hastanın bilinen tüberküloz maruziyeti yoktu. En sık başvuru yakınması lenf bezi lokalizasyonundaki şişlikti. Yakınma süresi ortanca $60 \mathrm{gün}$, min: 5- max: 4800 gündü. Lenf bezlerinin en sık yerleşim yeri servikal bölgedeydi. Tüberkülin cilt testi 15 (\%88.2) hastada, interferon gama salınım testi ise uygulanan 13 hastanın 12'sinde (\%92.3) pozitifti. Hastaların 12 'sinde (\%70.2) ön arka akciğer grafisi normaldi. Geri kalan beş (\%29.4) hastaya bilgisayarlı toraks tomografisi çekilerek, bir hastaya pulmoner tüberküloz tanısı konuldu. 14 hastaya lenf nodu biyopsisi yapıldı. Doku örneklerinin histopatolojik ve mikrobiyolojik incelemelerinde; iki (\%14) hastada Ehrlich-Zhiel-Neelsen boyama ile basil, beş (\%83) hastada Mycobacterium tuberculosis polimeraz zincir reaksiyonu ve bir (\%20) hastada M. tuberculosis kültür pozitifliği saptandı. Tedaviyi reddeden bir ve terkeden iki hasta dışında tüm hastalar antitüberküloz tedavi aldı.

Correspondence Address/Yazışma Adresi

Sevgi Yaşar Durmuş

Kayseri Şehir Eğitim ve Araştırma Hastanesi,

Çocuk Enfeksiyon Hastalıkları Kliniği,

Kayseri-Türkiye

E-mail: drsvgysr@gmail.com 
Yaşar Durmuş et al.

positivity was detected in one (20\%) patient. Apart from one patient denied treatment and two lost the follow up, remaining patients were treated with antituberculosis drugs.

Conclusion: Tuberculous lymphadenitis should be kept in mind espescially when the lymph nodes are firm and immobile, lasting minimum then one week, and do not heal with nonspesific antibiotic treatment.

Keywords: Child, lymphadenitis, tuberculosis

\section{Introduction}

Tuberculosis (TB) remains to be an important public health problem worldwide. According to the 2018 data of the World Health Organization (WHO), it is estimated that there are ten million new cases, one million of which are considered to be pediatric cases (1). As of 2017, TB incidence in our country has been reported as 14.6 in 100.000 (2). Tuberculosis is divided into two as pulmonary and extrapulmonary. In extrapulmonary TB, lymph nodes, pleura, meninges, pericardium, musculoskeletal system, gastrointestinal, and genitourinary systems may be involved (3). Extrapulmonary tuberculosis is seen more frequently in children than in adults. TB lymphadenitis comprises a majority of the childhood extrapulmonary tuberculosis cases (4).

Tuberculous lymphadenitis develops as a result of TB bacilli infiltration to the lymph node through lymphohematogenous route. Although it can involve all regional lymph nodes, cervical lymph nodes are most commonly involved. Lymphadenitis may be the only finding in $25-35 \%$ of pediatric cases with TB $(2,5)$. In addition, TB diagnosis can be delayed in patients presenting with non-specific lymphadenitis findings (4). Tuberculous lymphadenitis may heal spontaneously if left untreated. However, complications like fistulization and suppuration to the skin may develop in untreated patients $(2,5)$. Even though there is not definitive data on TB lymphadenitis mortality in children, it is an important cause of morbidity. In this study, it was aimed to present the diagnostic approaches and outcomes of treatment and follow-up by retrospectively evaluating the pediatric patients diagnosed with TB lymphadenitis in the Pediatric Infectious Diseases Clinic of our hospital.

\section{Materials and Methods}

Pediatric patients diagnosed with TB lymphadenitis in the Pediatric Infectious Diseases Clinic of our hospital between 2012 and 2019 were retrospectively reviewed using medical records. Age, sex, presence of an underlying disease, Bacille Calmette-Guerin (BCG) vaccination status and tuberculosis contact, presenting symptoms, symptom durations, physical examination findings, tuberculin skin test (TST) result, interferon gamma release test (IGRT) result, laboratory tests including complete blood count and acute phase reactants, radiological imaging findings, microbiological and histopathological findings, time elapsed between first presentation and diagnosis, antituberculosis treatment regimens, treatment durations and follow-up of the patients were recorded.
Sonuç: Özellikle sert ve cilde yapışık karakterde, en az bir haftadan uzun süredir sebat eden, nonspesifik antibiyotik tedavisine yanıt vermeyen lenfadenitlerde tüberküloz lenfadenit akılda bulundurulmalıdır.

Anahtar Kelimeler: Çocuk, lenfadenit, tüberküloz

Tuberculin skin test was performed with 5 tuberculin unit purified protein derivative injected intradermally on the inside of the left arm. If the widest diameter of the induration measured after 72 hours in the injection site was $\geq 10 \mathrm{~mm}$ for those without BCG vaccination and $\geq 15 \mathrm{~mm}$ for those with BCG computed thorax tomography vaccination, it was accepted positive (2). Interferon gamma release test (IGRT) was measured according to the recommendations of the manufacturer (QuantiFERON-TB Gold Plus QFT-Plus (Qiagen, Germany). Mycobacterium tuberculosis polymerase chain reaction (PCR) Gene Xpert MTB/RIF (Cepheid, Sunnyvale, CA) was performed in line with the recommendations of the manufacturer. A pediatric radiologist with more than 10-year experience retrospectively re-evaluated the superficial ultrasonography (USG) findings oriented at the lymph node, posteroanterior chest graphy and thoracic computed tomography (CT) findings over the "picture archiving and communication system, PACS". On the histopathological investigation of the excised material of the lymph node, it was seen that there was inflammation characterized by necrotizing or non-necrotizing epithelioid granulomas, a part of which containing Langhans type giant cells. Histochemical staining with Ehrlich-Ziehl-Neelsen (EZN) detected acid-resistant bacilli (ARB) in some cases. In cases with no bacilli, the cases were evaluated as TB by histopathological and clinical findings.

Tuberculous lymphadenitis diagnosis was made in the patients suspected of TB lymphadenitis clinically by seeing inflammation findings suggestive of TB in the histopathological evaluation of the tissue sample taken by excisional biopsy or fine-needle aspiration biopsy (FNAB) and/or by the positivity of microbiological tests sent from tissue samples $(2,6)$.

Windows-based SPSS 20.0 analysis program was used for statistical analyses. Descriptive statistics were performed for demographic data. Mean \pm standard deviation was calculated for variables determined by measurement, and percentage and frequency values were calculated for variables determined by enumeration. Local ethics committee approval was obtained for the study $(15.11 .2019,2019-11)$.

\section{Results}

Of the 40 pediatric patients diagnosed with extrapulmonary TB in our hospital between the years 2012 and 2019, 17 (42.5\%) had TB lymphadenitis. Of the patients, 10 (58.8\%) were girls, $7(41.2 \%)$ were boys with a girl to boy ratio as 1.4. The 
Table 1. Physical examination findings of lymph nodes

\begin{tabular}{|c|c|c|c|c|}
\hline Case no & Lymph node localization & Lymph node size & The number of lymph node & Lymph node characteristic \\
\hline 1 & Left submandibular & $3 \times 2 \mathrm{~cm}$ & 1 & Rigid \\
\hline 2 & Left upper anterior cervical & $3 \times 1 \mathrm{~cm}$ & 1 & Rigid \\
\hline 3 & Left supraclavicular & $0.5 \times 0.5 \mathrm{~cm}$ & 1 & Rigid \\
\hline 6 & $\begin{array}{l}\text { Right anterior cervical } \\
\text { Left anterior cervical }\end{array}$ & $\begin{array}{l}9 \times 5 \mathrm{~cm} \\
9 \times 7 \mathrm{~cm}\end{array}$ & 1 & Rigid \\
\hline 7 & $\begin{array}{l}\text { Left inguinal } \\
\text { Right inguinal }\end{array}$ & $\begin{array}{l}2 \times 1.5 \mathrm{~cm} \\
1.5 \times 1 \mathrm{~cm}\end{array}$ & 1 & Rigid, fixed, hyperemic rigid, fixed, hyperemic \\
\hline 8 & Left submandibular & $3 \times 2 \mathrm{~cm}$ & 1 & Rigid, fixed, hyperemic, fistulized to the skin \\
\hline 9 & Left upper cervical & $3 \times 3 \mathrm{~cm}$ & 1 & Rigid, fixed, hyperemic \\
\hline 10 & Right submandibular & $5 \times 3 \mathrm{~cm}$ & 1 & Hyperemic, fluctuating \\
\hline 11 & Right submandibular & $3 \times 2 \mathrm{~cm}$ & 1 & Rigid \\
\hline 12 & Right upper cervical & $4 \times 2 \mathrm{~cm}$ & 1 & Rigid \\
\hline 13 & Left upper cervical & $4 \times 2 \mathrm{~cm}$ & 1 & Rigid \\
\hline 14 & Right submandibular & $3 \times 3 \mathrm{~cm}$ & 1 & Rigid, fixed \\
\hline 15 & Right submandibular & $3 \times 2 \mathrm{~cm}$ & 1 & Mobile, painful \\
\hline 16 & Left upper cervical & $1.5 \times 1.5$ & 1 & Mobile, fluctuating \\
\hline 17 & Right axillary & $5 \times 5 \mathrm{~cm}$ & 1 & Rigid \\
\hline
\end{tabular}

age range was $5-192$ months, and the mean age was $88.7 \pm 63$ months. Thirteen patients (75.6\%) were vaccinated with BCG. The remaining 4 patients, whose parent did not know whether or not the paint received the BCG vaccine, did not have a scar. None of the patients had a known TB exposure. TB was not detected in families of 12 patients (70.2\%) whose contact screening results could be reached. No accompanying disease was present in 14 patients. One patient had simultaneous tularemia with TB lymphadenitis. During follow-up one patient was diagnosed with chronic granulomatous disease and another with interleukin (IL) 12 receptor beta1 deficiency.

Presenting compliants of all patients was swelling on the lymphatic gland localization. Weight loss was additionally seen in one patient, and discharge from the lymph node site in another. Duration of complaints was median 60 days (min:5- max:4800 days). The most common localization of the lymphatic gland was the cervical region in $9(53 \%)$ patients. Table 1 summarizes the physical examination findings of the lymph nodes of all patients except for two patients (cases 4 and 5) whose excisional lymph node biopsy was performed in another hospital and who had no palpable lymph node on physical examination.

Laboratory analyses showed peripheral white blood cell count as median $8800 / \mathrm{mm}^{3}\left(5240-19640 / \mathrm{mm}^{3}\right)$, median erythrocyte sedimentation rate (ESR) as $17 \mathrm{~mm} / \mathrm{h}(4-65 \mathrm{~mm} / \mathrm{h})$, and median C-reactive protein (CRP) level as $3 \mathrm{mg} / \mathrm{L}(1.4-45 \mathrm{mg} / \mathrm{L})$. Human immunodeficiency virus (HIV) antibody was negative in all patients. Tuberculin skin test was found positive in 18
(88.2\%) patients. Interferon gamma release test performed in 13 patients was confirmed positive in 12 (92.3\%). Prior to TB diagnosis, 11 patients (64.2\%) received oral or parenteral antibiotic treatment with a preliminary diagnosis of bacterial lymphadenitis. The most commonly used oral antibiotic was amoxicillin clavulanic acid (35.8\%), and the most commonly used parenteral antibiotic was ampicillin sulbactam (25.9\%). The patient diagnosed with tularemia also received gentamicin and ciprofloxacin treatments additionally. Duration of nonspecific antibiotic use prior to diagnosis was mean 8.5 ( \pm 5.8 ) days.

Posteroanterior chest graphy was normal in 12 of the patients (70.2\%). Three patients (17.6\%) had bilateral hilar distension and perihilar and peribronchial infiltration, one (5.9\%) had aeration increase accompanied by bilateral perihilar, peribronchial and right paracardiac infiltration, and another one (5.9\%) had bilateral paracardiac and peribronchial infiltration. No pathological finding was determined in four $(80 \%)$ of the five (29.4\%) patients who underwent computed thorax tomography. Patch-like nodular densities with peripheral localization were observed in 1 patient (20\%). Superficial USG findings of the lymph nodes of the patients are summarized in Table 2.

Lymph node biopsy was performed in 14 patients, in whom 13 had excisional biopsy and 1 had FNAB. On histopathological and microbiological examination of the tissue samples, bacillus with EZN staining was found in 2 patients (14\%), M. tuberculosis PCR in five patients (83\%), and M. tuberculosis positivity in one patient (20\%). Mycobacterium tuberculosis PCR from samples obtained through spontaneous drain- 
Table 2. Ultrasonographic findings of lymph nodes

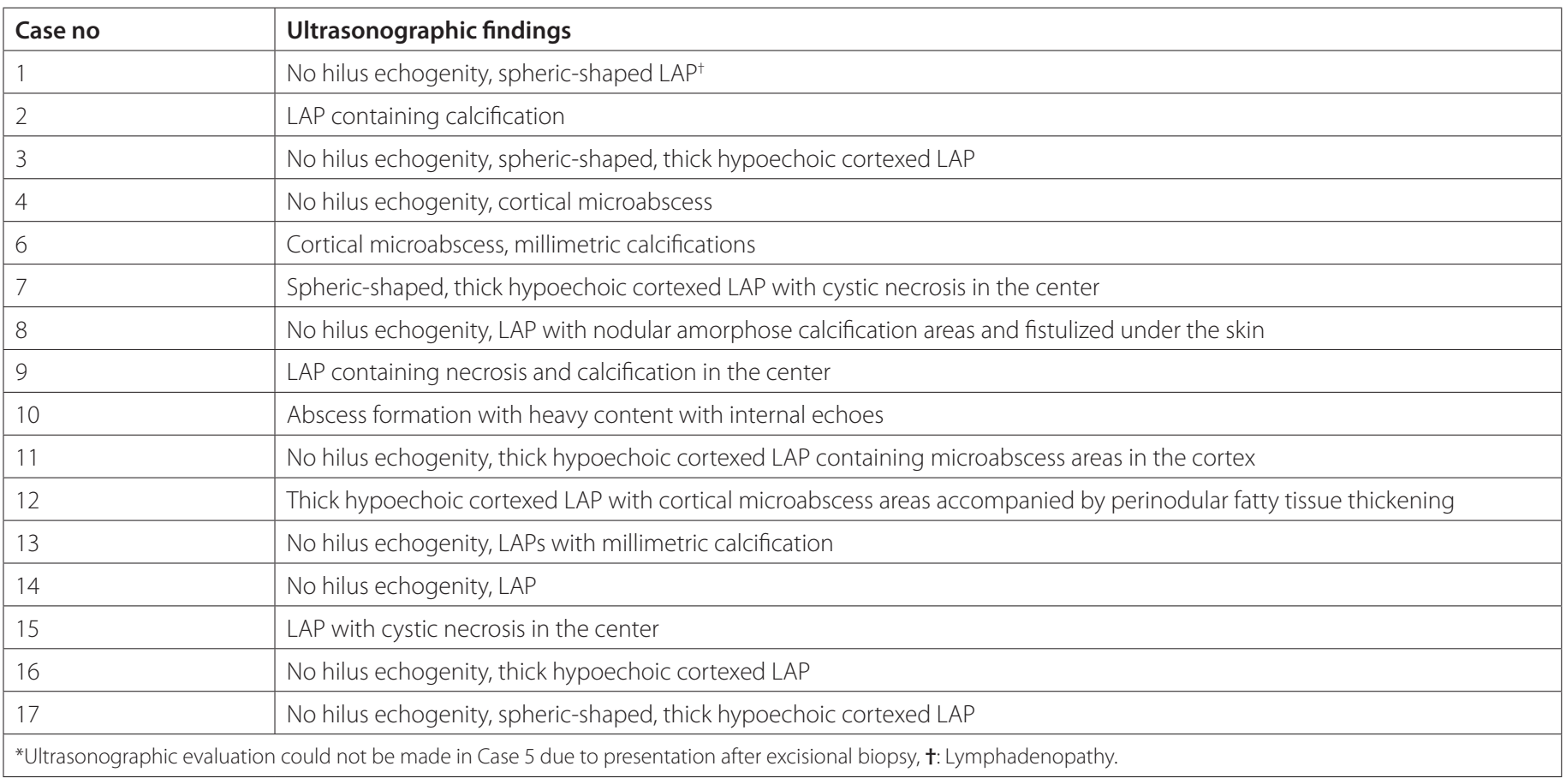

Table 3. Histopathological characteristics of lymph nodes that underwent excisional biopsy

\begin{tabular}{|l|c|}
\hline Histopathological characteristics & Number (\%) \\
\hline Necrotizing granulomatous inflammation & $7(50)$ \\
\hline Caseous granulomatous inflammation & $4(29)$ \\
\hline Caseous necrosis & $2(14)$ \\
\hline Granulomatous inflammation & $1(7)$ \\
\hline
\end{tabular}

age or abscess drainage was found positive in three patients in whom lymph node biopsy could not be performed. Table 3 summarizes the histopathological examination results of the patients that underwent lymph node biopsy.

Ten patients were started on a triple antituberculosis treatment with isoniazid $(H)$, rifampisin $(R)$, ethambutol $(E)$, and 6 patients were started on a quadruple antituberculosis treatment with $\mathrm{H}, \mathrm{R}, \mathrm{E}$ and pyrazinamide. One patient refused treatment and left the hospital before all tests could be completed and another one did not show up for control visits during treatment. The treatment of the remaining 14 patients was completed in 6 months. Mean follow-up period of the patients was 13 months (min: 2 months-max: 72 months). Table 4 shows the pre-and post-treatment lymph node sizes of the patients, biopsy methods, and follow-up durations.

\section{Discussion}

Tuberculosis of the lymph nodes referred to as "scrofula" that manifested spontaneously on the skin at past times when antituberculosis treatment was not present remains to be the most common form of extrapulmonary tuberculosis. Historically, TB lymphadenitis was most common in children and emerged most frequently due to $M$. bovis that spread through unpasteurized milk. However, it is the disease of young adults related to $M$. tuberculosis in developed countries. This change is probably based on the decrease in childhood TB incidence in developed countries (7). However, its most common form seen in developing countries like ours is extrapulmonary TB (5). In our study, the most common TB lymphadenitis was found as extrapulmonary TB.

In a 16-year retrospective study investigating 92 TB lymphadenitis pediatric cases in Argentina, mean age has been reported as $8.7 \pm 5$ years (8). Similarly, mean age in our study was detected as older than 7 years of age. In studies from our country TB lymphadenitis has been detected more commonly in females in both children and adults $(9,10)$. In our study, TB lymphadenitis was found 1.4 times fold in girls than in boys.

Of the pediatric cases with tuberculous lymphadenitis, $80 \%$ have been reported to have contact history with TB, and TST has been found positive in $90 \%$ of the patients (7). In a study including 108 peripheral lymphadenitis patients aged over 12 years in Korea, the sensitivity and specifity of IGRT have been reported as $90.6 \%$ and $80.2 \%$, respectively (11). Even though an index case was not determined in any of our patients, TST and IGRT were found positive at a high rate. Since TB is transmitted to children through adults, detecting TB in childhood shows that adult TB in the community is not sufficiently under control. Therefore, when TB is diagnosed in the childhood period, 
Table 4. Pre-and -post treatment lymph node sizes, follow-up durations and surgical methods employed

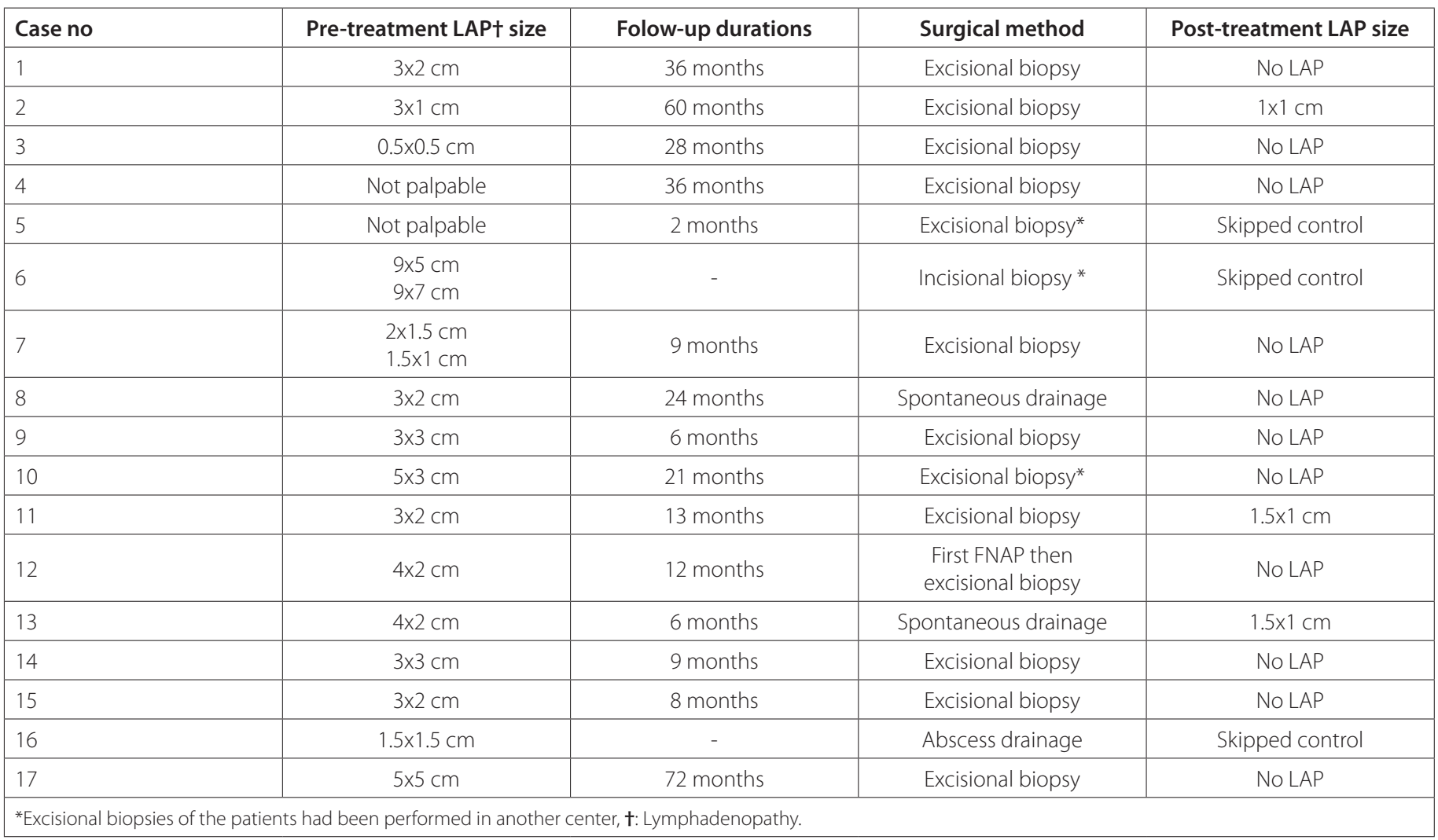

adults in contact with the child must be screened to find the index case (12).

Cervical lymph nodes are the most commonly involved lymph nodes in TB lymphadenitis. Along with the difference between countries, approximately $50 \%$ of TB lymphadenitis appear in cervically localized lymph nodes (13). In a retrospective study evaluating 102 children with extrapulmonary TB in Greece, it has been found in 48 patients with TB lymphadenitis that the most common localizations are anterior cervical and submandibular lymph nodes (14). Cervical lymph node involvement has been found as $80 \%$ in a study conducted in Argentina, and in a study including 19 TB lymphadenitis pediatric cases in Turkey, the same rate has been found as $57.8 \%$ $(8,10)$. In our study, lymph node localization in half of our patients was the cervical region.

Children with tuberculous lymphadenitis commonly present with a painless and slow-growing swelling on the involved lymph node region. In addition, mild fever, malaise, and weight loss can be seen $(7,9)$. In a study evaluating 16 pediatric patients with head-neck TB from Canada lymphadenitis, the only presenting symptom has been reported as swelling on the lymph node region (4). In a study from our country, regional swelling has been reported in 18 of the 19 pediatric cases and elevated fever in one (10). In our study, all patients presented with lymph node swelling. In tuberculous lymphadenitis, the structure of the lymph node is rigid, fluctuating with or without tenderness, adherent to the surrounding structure or can fistulize to the skin $(7,15)$. In our study, lymph node rigidity, adherence to the skin, hyperemia, fluctuation and fistulization to the skin were most commonly found. Due to the fact that tuberculous lymphadenitis does not have specific clinical characteristics, duration of symptoms of the patients prior to presentation is usually long and there is usually a history of non-responsive antibiotic treatment. In various studies conducted with children, mean duration of symptoms has been reported as $35-88$ days $(8,10,14,16)$. In our study, median duration of symptoms was 2 months, and two thirds of the patients had received nonspecific antibiotic treatment.

Routine laboratory tests are not helpful on their own in tuberculous lymphadenitis. ESR may be slightly or moderately high. In the event of a secondary infection, acute phase reactants may be detected high (7). Similar results were obtained in our study.

It has been reported that tuberculous lymphadenitis develops 6-9 months after latent TB infection. Findings compatible with pulmonary TB on the chest graphy of the patients have been reported at various rates (5). In a study including 73 TB lymphadenitis patients aged over 13 years from our country, findings in favor of TB on chest graphy have been reported as $12.3 \%(17)$. This rate has been reported as $18 \%$ in a review 
published from the United States of America (18). Thoracic CT has been reported to be superior to chest graphy in detecting small lesions in the lung parenchyma and in evaluating mediastinal lymph nodes (19). Even though pathological findings were detected in approximately one third of the patients, findings in favor of TB were detected on CT in one patient only. USG findings of TB lymphadenitis have been classified as 1) a hypoechoic LAP containing heterogenous echogenity or intranodal necrosis, 2) an indistinct nodal border, nodal matting, conglomeration, 3) presence of echolucent areas with indistinct borders in the perinodal soft tissue accompanied or unaccompanied by sinus or abscess formation, and 4) vascular pattern in which avascular areas are observed on Doppler or displacement in vascular structures (20). At least one pathological sonographic finding was present in all lymph nodes examined in our study. Having no hilus echogenity, thick hypoechoic cortex, cortical microabscess, and spheric configurations were the most common findings, central necrosis and abscess formation were found in five patients, and fistulization to the skin following abscess was seen in one patient. The incidence of intranodal calcification in tuberculous lymphadenitis has been reported a $24-84 \%$ in different studies (21). In our study, calcifications in the lymph node were seen in approximately $30 \%$ of the cases.

Fine needle aspiration biopsy, core-needle biopsy and excisional biopsy are commonly used in the diagnosis of TB lymphadenitis. Due to the possibility of developing chronic fistula and sinus tract with excisional biopsy, first option diagnostic method in cervical TB lymphadenitis is USG-guided FNAB. However, it has been stated that taking sufficient cytologic samples with this method could be difficult and recommended that excisional biopsy should be preferred in suspected TB lymphadenitis $(22,23)$. Tissue sampling in our patients was mostly done by excisional biopsy. In a study including 51 cervical TB lymphadenitis patients from England, biopsy results have been evaluated and results supporting that excisional biopsy causes chronic fistula or sinus development have not been obtained (23). Similarly, chronic fistula or sinus formation was not observed after the operation in any of our cases that underwent excisional biopsy.

The sensitivity of lymph node biopsy is $100 \%$ for histopathological evaluation and $60-90 \%$ for mycobacterial culture (24). In the pathology of tuberculous lymphadenitis, Langhans-type cells and tuberculosis granulomas accompanied or unaccompanied by caseous necrosis are seen. The sensitivity of pathological examination depends on the operation protocol and the structure of the obtained material among the samples (25). The most commonly observed histopathological finding in our study was granulomatous inflammation accompanied or unaccompanied by caseous necrosis. It is known that the positivity rate of EZN staining, which is the most fre- quently applied method in detecting acid-resistant bacilli, is $27-60 \%$ due to the fact that bacilli are scarce in the tissue, and positive staining result is not sufficient alone to make TB diagnosis. Mycobacterial culture, which is still the gold standard in diagnosis, gives late results. The sensitivity and specificity of TB PCR in cervical TB lymphadenitis are $45-75 \%$ and $97.3-$ $100 \%$, respectively. Gene Xpert MTB/RIF gives results in two hours in smear positive patients with $89 \%$ sensitivity and with $67 \%$ in smear negative patients (26). In our study, rate of incidence of bacilli with EZN staining and mycobacterial culture positivity were low in patients that underwent lymph node biopsy. The highest positivity among the tests performed to detect $M$. tuberculosis in the tissue in our study was confirmed in patients in whom M. tuberculosis PCR was performed (83\%).

\section{Conclusion}

In this retrospective, single-center study, it is concluded that lymphadenitis that is in a rigid character adherent to the skin, has persisted for over at least a week, and does not respond to nonspecific antibiotic treatment should be evaluated in terms of TB lymphadenitis, TST and IGRT positivity are high, lymph node ultrasonographic examination may be helpful in diagnosis, and definitive diagnosis should be based on histopathological and microbiological methods.

Ethics Committe Approval: This study approval obtained from SBÜ Dr. Sami Ulus Maternity and Child Health and Diseases Training and Education Hospital SUAM Board of Expertise in Medicine (Decision no: 2019/11 and Date: 15.11.2019).

Informed Consent: Patient consent was obtained.

Peer-review: Externally peer-reviewed.

Author Contributions: Concept - SYD, TAT, AK; Design - SYD, RY, FNÖ; Supervision - GT, FNÖ, TAT, ASE, IFÖ; Resource - SYD, RY, AK, ABÖ; Data Collection and/or Processing - SYD, ABÖ, ASE; Literature Search - SYD, GT, ASE, TAT, IFÖ; Writing - SYD, GT, ASE, ABÖ; Critical Review - All of authors.

Conflict of Interest: All authors declare that they have no conflicts of interest or funding to disclose.

Financial Disclosure: The authors declared that this study has received no financial support.

\section{References}

1. World Health Organization (WHO). Global tuberculosis report 2018. Geneva: World Health Organization, 2018. [CrossRef]

2. Tüberküloz tanı ve tedavi rehberi. Sağlık Bakanlığı Yayın No: 1129, Ankara: 2019. [CrossRef]

3. Gupta V, Bhake A. Diagnosis of clinically suspected and unsuspected tubercular lymphadenopathy by cytology, culture, and smear microscopy. Indian J Tuberc 2017;64:314-7. [CrossRef]

4. Xu JJ, Peer S, Papsin BC, Kitai I, Propst EJ. Tuberculous lymphadenitis of the head and neck in Canadian children: Experience from a low-burden region. Int J Pediatr Otorhinolaryngol. 2016;91:11-4. [CrossRef] 
5. Özgür Gündeşlioğlu Ö, Kocabaş E. Akciğer Dışı Tüberkülozda Klinik Özellikler. In: Özçelik U KE, Ersu R, Gürkan F editor. Çocukluk Çağında Tüberküloz Tanı, Tedavi ve Korumada Güncel Yaklaşımlar ve Olgu Örnekleri. 23. Ankara: Nobel Tıp Kitabevleri; 2017:17-25. [CrossRef]

6. Catano JC, Robledo J. Tuberculous Lymphadenitis and Parotitis. Microbiol Spectr 2016;4. [CrossRef]

7. Carrol ED, Clark JE, Cant AJ. Non-pulmonary tuberculosis. Paediatr Respir Rev 2001;2:113-9. [CrossRef]

8. Neyro SE, Squassi IR, Medin M, Caratozzolo A, Martinez Burkett A, Cerqueiro MC. Peripheral tuberculous lymphadenitis in pediatrics: 16 years of experience in a tertiary care pediatric hospital of Buenos Aires, Argentina. Arch Argent Pediatr 2018;116:430-6. [CrossRef]

9. Karagöz T, Şenol T, Bekçi TT. Tüberküloz Lenfadenit. Toraks Dergisi 2001;2:74-9. [CrossRef]

10. Bozdemir ŞE, Öztürk NH, Hacımustafaoğlu M, Çelebi Ş. Çocuklarda Tüberküloz Lenfadenit. J Pediatr Inf 2012;6:6-11. [CrossRef]

11. Kim YK, Uh Y, Lee NS, Cho MY, Eom M, Kim HY. Whole-blood interferon-gamma release assay for diagnosis of tuberculous lymphadenitis. Tohoku J Exp Med 2011;224:189-93. [CrossRef]

12. Karadağ B. Tüberküloz Epidemiyolojisi. In: Özçelik U KE, Ersu R, Gürkan F editor. Çocukluk Çağında Tüberküloz Tanı, Tedavi ve Korumada Güncel Yaklaşımlar ve Olgu Örnekleri. 23. Ankara: Nobel Tıp Kitabevleri; 2017:5-7. [CrossRef]

13. Mandal N, Anand PK, Gautam S, Das S, Hussain T. Diagnosis and treatment of paediatric tuberculosis: An insight review. Crit Rev Microbiol 2017;43:466-80. [CrossRef]

14. Maltezou HC, Spyridis $P$, Kafetzis DA. Extra-pulmonary tuberculosis in children. Arch Dis Child 2000;83:342-6. [CrossRef]

15. Working Group on Tuberculosis, Indian Academy of Pediatrics (IAP). Consensus statement on childhood tuberculosis. Indian Pediatr 2010;47:41-55. [CrossRef]

16. Tinsa F, Essaddam L, Fitouri Z, Nouira F, Douira W, Ben Becher S, et al. Extra-pulmonary tuberculosis in children: a study of 41 cases. Tunis Med 2009;87:693-8. [CrossRef]
17. Oktay MF, Topcu I, Senyigit A, Bilici A, Arslan A, Cureoglu S, et al. Follow-up results in tuberculous cervical lymphadenitis. J Laryngol Otol 2006;120:129-32. [CrossRef]

18. Lazarus AA, ThilagarB. Tuberculous lymphadenitis. Dis Mon.2007;53:105. [CrossRef]

19. Peng SS-F, Chan P-C, Chang Y-C, Shih TT-F. Computed tomography of children with pulmonary Mycobacterium tuberculosis infection. J Formos Med Assoc 2011;110:744-9. [CrossRef]

20. Moon IS, Kim DW, Baek HJ. Ultrasound-based diagnosis for the cervical lymph nodes in a tuberculosis-endemic area. Laryngoscope 2015;125:1113-7. [CrossRef]

21. Ryoo I, Suh S, Lee YH, Seo HS, Seol HY. Comparison of Ultrasonographic Findings of Biopsy-Proven Tuberculous Lymphadenitis and Kikuchi Disease. Korean J Radiol 2015;16:767-75. [CrossRef]

22. Kim DW, Jung SJ, Ha TK, Park HK. Individual and combined diagnostic accuracy of ultrasound diagnosis, ultrasound-guided fine-needle aspiration and polymerase chain reaction in identifying tuberculous lymph nodes in the neck. Ultrasound Med Biol 2013;39:2308-14. [CrossRef]

23. Moualed D, Robinson M, Qureishi A, Gurr P. Cervical tuberculous lymphadenitis: diagnosis and demographics, a five-year case series in the UK. Ann R Coll Surg Engl 2018;100:392-6. [CrossRef]

24. Benjelloun A, Darouassi Y, Zakaria Y, Bouchentouf R, Errami N. Lymph nodes tuberculosis: a retrospective study on clinical and therapeutic features. Pan Afr Med J 2015;20:65. [CrossRef]

25. Smaoui S, Mezghanni MA, Hammami B, Zalila N, Marouane C, Kammoun $S$, et al. Tuberculosis lymphadenitis in a southeastern region in Tunisia: Epidemiology, clinical features, diagnosis and treatment. Int J Mycobacteriol 2015;4:196-201. [CrossRef]

26. Pang P, Duan W, Liu S, Bai S, Ma Y, Li R, et al. Clinical study of tuberculosis in the head and neck region-11 years' experience and a review of the literature. Emerg Microbes Infect 2018;7:4. [CrossRef] 